\title{
Poverty, Infidelity and Oppression in Festus Iyayi’s Violence
}

\author{
Nwabudike Christopher Eziafa (Corresponding author) \\ Department of Language and Communication Studies, Federal University, Dutsin-Ma \\ Anaso George Nworah \\ Department of Language and Communication Studies, Federal University, Dutsin-Ma
}

Received: 20-08-2015

doi:10.7575/aiac.ijclts.v.3n.4p.49
Accepted: 31-09- 2015

Published: 31-10- 2015

\begin{abstract}
This paper takes a cursory look at the subjects of poverty, infidelity and oppression in Festus Iyayi's Violence. Using Malinowski and Radcliffe Brown's Functional approach to literature as a framework, the writers peer into the society with the intent of exposing the ills bedeviling the people. The preponderant penury has been decried; the cruelty of infidelity and immorality has been denounced as well as the dehumanizing oppression of the poor by the rich. The study concludes with a call on the government and well-meaning members of society to stand and overcome these three maladies.
\end{abstract}

Keywords: Poverty, Infidelity, Oppression, Violence

\section{Introduction}

In Violence (1976), Festus Iyayi has presented the poor condition of many people in his country in the midst of the abundance from the oil boom of the 1970's. As a protest writer, Iyayi takes a philosophical look at the neo-colonial setup in Nigeria and declares Violence as its guiding principle. Idemudia's father like other farmers of his calibre produces the entire nation's wealth but lives in abject poverty, which is the direct source of enmity, mutual suspicion and alienation that destroys his household. Idemudia unavoidably drops out of school and goes to the city in search of a job which he never finds. Idemudia actually represents a million unemployed able-bodied, homeless and hungry in a land of abundance as shown in hotels and beautiful edifices scattered everywhere and the dustbins of some filling to overflowing with remnant of delicious food. Due to the difficulty of getting jobs, men sell their blood in order to feed their families; and women resort to infidelity to save their dying husbands. The hospitals are filled with heartless nurses. Other social infrastructures like roads, electricity, etc are also nothing to write home about.

In the midst of these hopeless conditions, is the glaring opulence of a few like the Obofuns who go about in ostentatious and prestigious cars, own a lot of houses, factories, hotels and concubines that are all acquired with public money through contract inflation and non-performance or outright embezzlement. The word "Violence" which means physical aggression against people and property such as armed robbery, is given a different meaning by the novel which declares that acts of violence are committed when a man is denied the opportunity of being educated, of getting a job, of feeding himself and his family, of affording medical attention in time. The perpetrator is the society, the type of economic-cumpolitical system which is operated in the country that brutalizes the individual and rapes his manhood. And when such men of poor and limited opportunity react, they are only in a certain measure answering violence.

The dominant structural element in Violence therefore, is the opposition of the oppressors and the oppressed. The questions that readily come to mind are, (1) Are the events in the novel a true picture of the Nigerian society? (2) Are men denied the opportunity of being educated; of getting jobs, of feeding themselves and their families, of medical attention, in the society? These and other questions shall be answered in this essay. In his second novel, Contract, Iyayi yields the stage to the infinite appropriators, so that we can see them clearly in all their bizarre adornment. Those who are guilty of immorality are not only those in the "Multiple Way Hotel", but also those in the offices and mansions. They include governors, their administrators, the colonial officials, the business men, the police and the army. The alarming effects are evident not only in multi-million naira embezzlement but also inferior and badly constructed roads, hospitals, markets, stadia, public parks, pervasive filth scum, squalor and poor population.

The scheming for the multi-million naira Ogbe City Council contract for the low cost houses knows no limit. The Chairman, Chief Ewe Obala, wants his son Ogie as a member of the contract award committee so that his percentage out of the expected kickback would be higher. Ogie, after initial resistance to the crime finally succumbs, although he wants his own share of the kick-back kept in the country as against his father's preference for Swiss Banks. On the eve of his father's departure, the son schemes with accomplices and proceeds to remove his own share of the money from the Swiss bank, but this ends tragically as the father mistakes the son for a robber and fatally shoots him.

The novels teach us that our society is alienation-ridden, stands on avarice, and runs on unbridled rapine; the situation indeed warps the ethical code of man, undermines his moral development, dehumanizes him and mortgages his feelings 
for the vernal needs of survival. It degrades human virtues such as love, honesty, sympathy etc to marketable commodities. It is suicidal to attempt to be good in such society. Appeals to all the supernatural deities in mosques, churches and shrines would not help for their contribution to the mess is itself enormous. Recourse to abstractions such as justice will also not help because society has turned justice to a word coined by the rulers to legitimize their unjust rule. Are we then at a dead end? The novels answer No, and recommends the second step to dis-alienation; correct historical perception of our alienating order.

In Violence, Idemudia begins by seeking the pervasive iniquities in individual, personal terms. He blames. his father., for being poor and unable to finance his education, but after passing through the furnace of experience, he realizes that poverty is never by choice as there are many structures in society that are tailor-made to confine the majority to penurious scavengers. He has come to the full awareness. Appropriately, he quickly understands his wife, Adisa's forced infidelity rather than beheading her as he earlier promised.

It is a mark of Iyayi's artistry, that his disarmingly innocent and simple language in the novel carries very advanced and explosive politics. One other crucial point prevails in the characterization and structural arrangement of the narrative of the oppressed masses: the oppressors too need some pity for, in the final analysis, oppression basically dehumanizes, whether one is the giver or the receiver. But since the oppressors are incapable of any act of liberation, this humanizing duty falls directly on the oppressed to make impossible all the conditions that make oppression a "sine quo non" of their daily existence. If ever we need the novelist as teacher today, Iyayi is definitely a foremost contender to the title.

\section{Concerns with Poverty}

Poverty has been defined as, "An insufficiency of goods and services measured by the standard of a given society, and at a given time" (Encyclopedia Britanica 16:499). Poverty is thus a relative condition. Internationally, Asiatic and African countries are more poor compared to Latin-American countries, which in turn are poorer than Europe or North American; Eastern Mexico compared to the United States; Mainland Asia compared to Japan. What Violence portrays is Class poverty:

A condition of constant struggle for survival, unemployment and underemployment; it is also associated with low wages, miscellaneous unskilled occupations, child labour, the absence of food reserves in the home, the pattern of frequent buying of small quantities of food many times a day as the need arises, pawning of personal goods and the use of second hand clothing and furniture. The social and psychological results of this type of poverty include living in overcrowded quarters, lack of privacy; high incidence of alcoholism, frequent resort to violence in the settlement of quarrels; frequent use of physical violence in the training of children; wife beating, early initiation into sex free union or consensual marriage; a relatively high incidence of the abandonment of mothers and children; high trend toward mother-centred families and a much greater knowledge of maternal relatives; the predominance of the nuclear family; a strong predisposition to authoritarianism; and a great emphasis upon family solidarity - an ideal only rarely achieved (Encyclopedia Britanica volume 16:499).

The foregoing is the exact picture depicted in Violence. The first chapter opens with Idemudia and his wife, Adisa, as tenants living in one of the low mud but zinc houses along Owode Street. Owode Street is always over flooded any time the rain falls and houses collapse, sometimes trapping human beings in them. Idemudia does not fear that his house will collapse, because even if it does he will not lose much property, after all what are one eight-spring iron bed, a short broom, a table and few cooking utensils? Idemudia lives in a room with a badly cemented floor, without radio in his house and food to eat. He says to his wife, "But you see me going out each day. Do you think I go to lyaro and First East Circular on an empty stomach for mere fun of it?" (2).And out of bitterness, Adisa replies, "You go out each day and return each day... with what? Is the coming back any better than going away? Look at me' I am getting leaner and thinner..." (3).

Idemudia could not complete his secondary school education because there was no money. His father and his uncle had to run into the bush to avoid harassment from tax collectors and Idemudia suffered for it .Now that he has come to the city, he could not find a job. He and his wife have to fight over lack of food. Idemudia is ready to borrow some money, even if only one naira, so that he and his wife could eat! But he does not know who will lend him the money? Friends are few indeed. Nobody will lend him the money, knowing full well that he has not the means to payback. But how surprising and disheartening to know that while hunger is cruelly destroying the four walls of Idemudia and Adisa's stomachs, unfinished jollof rice, dodo (fried plantain), meat and beans, are being emptied into the dustbin of the Obofuns. The condition of Idemudia, his wife, and other poor people can be likened to Richard Ntiru's Pauper who "sits alone in hairless goatskin... ribs and bones reflecting the light that beautiful cars reflect..., squashing lice between... nails and cleansing..., nails with dry saliva"(The Pauper by Richard Ntiru). But Idemudia is not the only person in this condition; his friend, Osaro, cries at the wastage of food in the houses of the rich few: "It is so unfair... One man has enough to eat, in fact so much that he throws some away, yet here we are, hungry with nothing to eat" (20).

To get something to eat, Idemudia and his friends have to agree to offload three full trailer loads of cement at the price of five Naira for each person. But who could have told Idemudia that this job would make him break down, be severed from his home for some weeks and spend more than double of this money in the hospital! For more than four hours, the men labour to clear the cement: their backs ache, their stomachs ache, their heads ache also but the work has to go on 
because they are hungry and because they need the money to buy food. Idemudia is particularly glad to have the money (five naira), because this will make him free from hunger and from want, at least for a while. As his wife is taking him to the hospital, he tries hard to fight the disease; he keeps telling himself, that he has to be strong; he has to get another job soon, because the money he has brought some time ago would soon be gone and again they would be plunged into despairing hunger.

At the hospital, children cry, women weep, everywhere there is a great urgency and, paradoxically, little activity: a hopelessness and helplessness that compel the observer to tears. It is simply a wonder why with so much challenge, these people still struggle and aspire to keep their lean flames of lives going. There seems to be no point in seeking recourse from death, evidence of enough distress and frustration abounds. And yet, even the women weep and the children cry and the men sit or stand about with watery eyes coughing and spitting and occasionally going to the fence to urinate. There is in each pair of eyes a stubborn determination not to let go of life no matter how filthy and degrading it is. Along the street people sit and watch the weather. Men and women, all jobless, sit on long wooden benches, their backs against rough mud walls. The children are mostly naked, thin and have legs full of sores, from which they frequently drive flies away. Most of the people who walk along the streets are barefoot and as the cars pass, some of them Mercedes Benz cars, splash red muddy water on the people and drive on carelessly, their owners secure inside. In the market, multitudes of people bargain in hard impersonal voices. Naira notes change hands and numbers of kobos are handed back. There is so much that could have been bought and yet there is little or no money. The majority of the people leave the market disappointed by soaring prices..

But there is actually no limit to what poverty can push people to do; it can push an otherwise faithful into adultery, a pious individual into the telling of lies, an honest man into stealing, a loving husband into abandoning his wife and children, a shy woman into shunning her known principle and going a borrowing, a loving father into becoming a wife and children's beater, recovered patients into planning to run away from hospitals in order to escape the cut-throat bills and an individual to sell his own blood (his life,) in order to survive. These are the unpredictable and innumerable effects of poverty.

\section{The Subject of Infidelity}

Even though the subject of infidelity was mentioned earlier, it is needful to dwell on it more extendedly due to its prominence in the novel. To begin by defining, the Oxford English Dictionary volume five defines "infidelity" as "unfaithfulness or disloyalty to a person, e.g to a sovereign, 1ord, master, friend, lover, especially to a husband or wife, called more fully, conjugal infidelity. Infidelity also means faithlessness or disbelief in religious matters"(260). However, this paper concentrates on the subject of infidelity concerning unfaithfulness to the marriage contract, manifested by having extra-marital sexual affairs.

Adisa, in Violence represents the group of people that indulge in infidelity because of poverty. Her husband has just recovered from illness and some amount of money is needed to pay the hospital bill before he can be discharged. Besides, there is no food at home. Against her will, she commits adultery with Obofun who had promised her money, some cartons of gin and lace materials. As her conscience pricks her, she voices out, "God knows how ashamed I am now, but he knows too it was a sacrifice I had to make for my husband's sake. Greater love had no man than the One who laid down his life for the life of his friend. I have done that, committed adultery for his sake. Surely, I shouldn't be punished for that" (207). Even her husband, Idemudia, understands Adisa's reason for committing adultery. His only reason for protest is that Adisa did not tell him what she had done.

Queen exemplifies those who indulge in infidelity in order to get what they want. She commits the act to get contracts and provision from government officials and favour from her employees. She goes into it when her husband opens a supermarket for her and she has to go out to make purchases. She finds out that getting the things she wants is not easy, and so has to go through the back door to get them. The men at the government wholesale centres will rather have affair with her than having her money. Even the notes given to her by her husband are despised. She discovers that the men will be willing to offer her contracts and money freely if only she agrees to yield to them. She could get whatever she wants; she only has to look and say, "This is what I want', If you give it to me, you will..."(191). The men also understand and give in to her and do the things she wants for her. Initially, her conscience pricks her after having an affair with a man, but gradually, she loses her conscience because of the thousands of naira that come to her. She is bold to tell her husband, "I have slept with your friends! I have enjoyed myself as much as you have. And whose fault is it? I should have sat here shouldn't I, washing your pants after you have soiled..." (191).

Another cause of infidelity in Violence is the attitude of "Nothing goes for anything". This is actually linked to Queen's posture of using what you have to get what you want. In Violence, characters like Iriso and Obofun represent this category of people. They believe that to help a woman, they must have carnal knowledge of her. Iriso, an officer in the Ministry of Agriculture insists that Queen must pay him for the milk and eggs supplied her, not with money, but with her body. He attempts to take Queen to the bed, and when she puts up slight resistance, Iriso reminds her: "And the milk and the eggs? After everything I supplied you? After all the risks, the expectation!" Queen replies: "I am going to pay!" Iriso answers: I don't want any money...Y You know what I want (99). The next person in this category is Obofun, a big business man. Adisa and her husband are in need and Obofun realizes this. But before he can offer help at all, Adisa must have to do something; offer her body because nothing goes for anything. Adisa insists that, that will be adultery, but Obofun replies: 
This is no adultery...We do it because of something you need. Where is the adultery there? I have told you I'll give you the drinks at the lowest price ever. Then I'll give you another fifty naira so that you can start off in your own trade. Do you call that adultery? Do you still insist that it is indeed adultery?

Adisa replies:

I don't know anything...I only know that when a

Married woman sleeps with another person who is not her husband, then it is adultery. I want to go home. Please let me go.

Obofun answers:

I will let you go...But you can always come back

any time you want the drinks. I am not forcing you (129).

Indeed, helpless Adisa has no choice than to go back few days later, and eventually, Obofun has his way, satisfying his flesh like a vulture picking at a corpse.

Some other people who are guilty of infidelity are those who are abandoned by their partners. Adisa's aunt, who advises and encourages her to go after other men, tells her that she (the aunt) started indulging in the act of infidelity because her husband abandoned here. Her husband gave himself over to drinks, beat her mercilessly, forgot his responsibility of caring for his family, borrowed money in her name and ran away from her; and because she and her children had to feed, clothe themselves, and pay the house rent, she had no alternative than to allow other men to have affair with her and help her out. She tells Adisa that no man is worth suffering for; you sacrifice everything for them and what you get in return is nothing but beating and desertion. She advises her further: "You are still a beautiful woman, Adisa. And if you had lived as long as I have, you would know that now is the time to abandon your man" (47).

As to whether Iyayi is fair enough to his characters regarding the issue of infidelity, we feel that the author has not just exaggerated the matter neither has he been unnecessarily hysterical; this is because unfaithfulness in the marriage contract has reached an epidemic level that is destroying society. Cases of marital infidelity and divorce abound; the likes of Obofun and Iriso who use their wealth and privileged positions as baits to entice and lure other people's wives into sexual immorality are unfortunately common in our society.

Also, there are many "Queens" around who go to any length to use their "bodies" to get what they want. They win contracts, competitions, amass wealth, and establish businesses here and there, not with their "sweat", but with their "bottom power." As seen in the above, Violence has repeatedly depicted the subject of infidelity just as it has done that of poverty which was considered earlier as well as that of oppression (which will be considered next).

\section{The Subject of Oppression}

The subject-matter of oppression is very pronounced in Violence, and the one that makes the content of the novel to justify its title and vice-versa. Oppression is defined as "An act of oppressing, tyranny, a feeling of distress or being weighed down, dullness of spirit, pressure" (Chambers Dictionary, 1186 ). The rich people, the government and government agents are the perpetrators and perpetuators of oppression in Violence. Common men and women are distressed, weighed down; they are despairing from the ordeals of their circumstances. These victims of oppression are the children of tears; there is nothing that they can do to save themselves from their situation as they have already been incapacitated by poverty. Their situation compares with that of the Jews in Egypt where they had to make bricks without been given straw; it also compares with that of the blacks in South Africa under the cruel and brutal hands of the apartheid. Worse, the oppressed in Violence actually seem beyond redemption.

The men in Violence are denied the opportunity of being educated, of getting jobs so as to fend for themselves and for their families; they are therefore unable to also afford medical attention. All these things are caused by a society whose economy and politics brutalize its members and rape them of personhood. The dominant structural element in Violence is the opposition of the oppressors and the oppressed. For instance, Idemudia the protagonist is denied the opportunity to be educated; thus, even as he comes to the town, he cannot find any job to take care of himself and his family. Even when he becomes an employee of the Obofuns, things do not change significantly. He and his colleagues work so hard and are paid so little. Appeal to Queen Obofun could not yield any good result as complaint incurs her wrath. The situation at the building site becomes so terrible that one of the workers cries out, "Things are so bad!...We earn so little and yet we are worked harder than slaves. When you point it out, she dismisses you" (246).

To make matters more painful, scattered all over the place, especially at the government reserved areas are the houses which the sweat and labour of the oppressed have already erected. Life in those reserved areas is ablaze because labour has left a positive mark there, the labour of hundreds of thousands of workers, working either in the intense sunlight, in the biting cold or in the blinding rain, piling the blocks higher and higher and wiping the salt and the sweat from their eyes, at their foreheads with the backs of their hands, being underpaid, underfed and treated no better than slaves. The employers who live in these homes are the unfeeling class of exploiters, greedy money-makers, conservative and reactionary public officials who in the end take all the credit for the achievements of labour, just as the slave drivers took all the credit for the achievement of the slaves.

An attempt to use Violence as lens to view contemporary society reveals that the picture Iyayi has painted is very accurate. Our society is supposedly united, democratic and egalitarian, but judging from the things seen, heard, and read every day, one will be easily convinced that the country is far from what it claims to be. It is disheartening to know that in some parts of the society, there is discrimination even in the offer of employment: indigenes are given jobs on 
permanent basis, whereas non-indigenes are given jobs on contract basis. To worsen the situation, contract gratuities are either delayed unnecessarily or not paid at all.

Educationally, indigenes enjoy free education while non-indigenes pay exorbitant school fees, in some parts of the country. In some other parts where indigenes pay at all, they pay only a paltry sum while their non-indigene counterparts are milked. Moreover, admissions into schools are denied some, simply on the grounds of religious differences. Sometimes, people are told to change their religion if they would be offered admission into primary, secondary and tertiary institutions. In the civil service and sometimes in private companies, people are denied their promotional rights as a result of tribalism and sectionalism. On the other hand, some are promoted even when they are not qualified for it, because of nepotism and favoritism. Also, many innocent civilians have suffered harassment and brutality in the hands of the police force, especially at check points; some have even been killed illegally.

Again, some teachers in schools, colleges and universities sometimes victimize their students, either because they refuse to yield to their carnal demands or fail to comply with their cruel and selfish instructions. Landlords are not left out in this general oppression perpetrated in the society. They increase their rent indiscriminately and without any human feeling. To them, it is either you pay or you pack out. And they send their tenants packing, giving them only one day notice. Some landlords even assault their tenants and sometimes kill them.

\section{Conclusion}

As a social critic, Iyayi has exposed the evils in the Nigerian society. He attacks corruption, exploitation and imposed poverty in Nigeria. Violence presents the daily struggles of an impoverished couple, cruelly manipulated by a rich business woman. In doing this, it also portrays Nigeria's extremes of poverty and wealth, peculiar forms of arrogance and the divisions in society. Such vices that characterized the society are exploitation, conjugal infidelity and general oppression.

\section{References}

Alka1i, Z. (1984).The Stillborn. Lagos: Longman. Print.

"Poverty"(1968). Encyclopaedia Britannica Volume 16.Chicago: William .Benton Publishers.Print.

"Infidelity"(2006) The Oxford English Dictionary. Oxford: Oxford University Press. Print.

Iyayi, F. (1976). Violence Lagos: Longman. Print.

Mohammed, A.Y. (1987). “The Cry for Justice in Peter Abraham’s Tell Freedom and Mine Boy.” Unpublished B.A. Project, University of Maiduguri.

Nwapa, F. (1966). Efuru.Britain: Cox and Wyman Limited. Print.

Ogunbiyi, V. (1988) Perspective on Nigerian Literature 1700 to the present, Volume Two. Lagos: Guardian Books Nigeria Limited. Print.

“Oppression” (1997) Chambers Dictionary. Edinburgh: Chambers Harrap Publishers LTD. Print.

Osso, N. (1990) Who's who in Nigeria. Lagos: Newswatch Communication Limited. Print.

Ntiru, R. (1975). “The Pauper” in Wole Soyinka's Poems of Black Africa. Great Britain: Martin Secke and Warburg Limited. Print. 